\title{
PENGARUH RASIO KEUANGAN TERHADAP PEMBIAYAAN MURABAHAH DI BANK PEMBIAYAAN RAKYAT SYARIAH ADECO LANGSA TAHUN 2013-2016
}

\author{
Yupin Kirana Siagian, Iskandar Budiman, Early Ridho Kismawadi \\ IAIN Langsa \\ yupinkirana@gmail.com
}

\begin{abstract}
The independent variables in this study are deposits and financial ratios of sharia banks which consist of NPF and FDR ratios. This study aims to determine and analyze the effect of DPK, NPF and FDR on Murabahah financing in the SRB. This study used secondary data, which is the form of published Financial Statements of banks obtained from the website of Bank Indonesia. The bank's financial report used is quarterly financial report at Adeco Langsa Syariah Adequacy Bank. The data were then analysed by using the classical assumption method using multiple linear regression analysis, determination coefficient, $\mathrm{F}$ test or simultaneous test and $\mathrm{t}$ test or partial test. Hypothesis in this research is DPK, and financial ratio of NPF and ROE bank partially has significant effect to Murabahah financing, while simultaneously from the three variables have a significant effect on the provision of financing. The method used in this study is multiple regressions. The results of this study indicated that DPK and FDR variables have no significant effect on murabahah financing, while NPF affects.
\end{abstract}

Keywords: Third Party Funds, Non Performing Financing (NPF), Financing to Deposit Ratio (FDR) and Murabahah Financing.

\begin{abstract}
Abstrak
Variabel independen dalam penelitian ini adalah DPK dan rasio keuangan bank syariah yang terdiri dari rasio NPF dan FDR. Penelitian ini bertujuan untuk mengetahui dan menganalisis pengaruh DPK, NPF dan FDR terhadap pembiayaan Murabahah pada BPRS. Dalam penelitian ini menggunakan data sekunder. Data yang digunakan berupa Laporan Keuangan bank yang dipublikasikan yang didapatkan dari website Bank Indonesia. Laporan keuangan bank yang digunakan adalah laporan keuangan triwulan pada Bank Pembiayaan Rakyat Syariah Adeco Langsa. Alat analisis yang digunakan adalah dengan metode asumsi klasik menggunakan analisis regresi linier berganda, koefisiensi determinasi, uji $\mathrm{F}$ atau uji simultan dan uji $\mathrm{t}$ atau uji parsial. Hipotesis dalam penelitian ini adalah DPK, dan rasio keuangan bank NPF dan
\end{abstract}


ROE secara parsial berpengaruh secara signifikan terhadap pembiayaan Murabahah. Sedangkan secara simultan dari ketiga variabel tersebut berpengaruh secara signifikan terhadap pemberian pembiayaan. Metode yang digunakan dalam penelitian ini adalah regresi berganda. Hasil dari penelitian ini menunjukkan bahwa variabel DPK dan FDR tidak berpengaruh secara signifikan terhadap pembiayaan murabahah, sedangkan NPF mempengaruhi.

Kata Kunci : Dana Pihak Ketiga, Non Performing Financing (NPF), Financing to Deposit Ratio (FDR) dan Pembiayaan Murabahah.

\section{PENDAHULUAN}

Menurut UU negara republik Indonesia No.10 tahun 1998 tanggal 10 November 1998 tentang perbankan, yang dimaksud dengan bank adalah badan usaha yang menghimpun dana dari masyarakat dalam bentuk simpanan dan menyalurkan kepada masyarakat dalam bentuk kredit dan atau bentukbentuk lainnya dalam rangka meningkatkan taraf hidup rakyat banyak. Jenis bank di Indonesia dibedakan menjadi 2, dibedakan berdasarkan pembayaran bunga / bagi hasil usaha yakni bank yang melakukan usaha secara konvensional dan bank yang melakukan usaha secara syari'ah (Ratna dkk, 2008).

Pembiayaan adalah penyediaan uang atau tagihan yang dapat dipersamakan dengan itu berdasarkan persetujuan atau kesepakatan antara bank dan pihak lain yang dibiayai untuk mengembalikan uang atau tagihan tersebut setelah jangka waktu tertentu dengan imbalan atau bagi hasil (Muhammad, 2005).

Banyak faktor yang mempengaruhi bank dalam menyalurkan pembiayaan, baik faktor yang berasal dari internal maupun faktor yang berasal dari eksternal bank. Untuk melihat kondisi internal perusahaan, biasanya pihak bank merujuk pada laporan keuangan bank yang diindikasi dengan berbagai rasio keuangan. Kondisi internal perusahaan dilihat dari beberapa rasio keuangan. Dalam penelitian ini, variabel independen menggunakan faktor yang berasal dari internal perusahaan yaitu rasio keuangan bank, ini 
dimaksudkan untuk kemudahan dalam metode serta kemudahan data. Faktor internal perusahaan juga mempengaruhi jumlah pembiayaan murabahah yang disalurkan seperti Dana Pihak Ketiga. Beberapa rasio keuangan yang sering digunakan untuk menilai kondisi internal perusahaan adalah rasio Non Performing Financing (NPF) dan Financing to Deposit Ratio (FDR) (Ferial Nurbaya, 2013).

PT. BPRS Adeco merupakan perbankan pertama yang kantor pusatnya di wilayah timur di Ibukota Provinsi Aceh. Bank BPRS Adeco didirikan pada tanggal 23 Maret 2007 dengan pendiri dan pemegang sahamnya sebagian besar dari tokoh, pengusaha, dan imtelektual berdomisili di Jakarta. Bank BPRS Adeco beroperasi berlandasan prinsip syariah dalam memenuhi kebutuhan masyarakat sebagai mitra usahanya di provinsi Aceh. Berikut adalah tabel ikhtisar keuangan PT. BPRS Adeco pada tahun 2005:

Tabel 1: Ikhtisar Keuangan BPRS ADECO Tahun 2013-2016

\begin{tabular}{|l|l|l|l|l|}
\hline Tahun & $\mathbf{2 0 1 3}$ & $\mathbf{2 0 1 4}$ & $\mathbf{2 0 1 5}$ & $\mathbf{2 0 1 6}$ \\
\hline Total Aktiva/Aset & $9,107,565$ & $11,825,536$ & $17,775,601$ & $23,315,949$ \\
\hline Total Pembiayaan & 137,000 & 108,000 & 250,000 & 370,700 \\
\hline Total Dana Pihak Ketiga & $2,600,270$ & $4,145,018$ & $5,090,301$ & $2,600,270$ \\
\hline Total Modal Disetor & $3,700,000$ & $4,200,000$ & $4,200,000$ & $4,500,000$ \\
\hline Total Ekuitas & $3,712,637.96$ & $9,774,167.51$ & $9,806,405.38$ & $4,449,867.57$ \\
\hline
\end{tabular}

Sumber: Laporan Tahunan BPRS Adeco, 2016

Disamping kelengkapan data yang dimiliki, PT. BPRS Adeco menjadi objek penelitian dikarenakan pertumbuhan bisnis PT. BPRS Adeco dari tahun ke tahun berjalan baik. Pada tahun 2016 pertumbuhan PT. BPRS Adeco berjalan dengan cukup baik. Dapat dilihat pada tabel 1.3, Aset tumbuh 31,16\% menjadi Rp.23,315,949,000 dari posisi Rp.17,775,601,000 di tahun 2015. Sebagai pelopor bank syariah di Indonesia, PT. BPRS Adeco berhasil meningkatkan pembiayaan maupun penghimpunan dananya. Total Pembiayaan dan Total Dana Pihak Ketiga juga mengalami peningkatan setiap tahunnya. Perkembangan di sisi penyaluran pembiayaan juga menunjukkan posisi BPRS 
Adeco yang kuat di tengah industri Bank Syariah Nasional dimana setiap tahunnya total pembiayaan yang diberikan semakin meningkat.

Penelitian ini mengacu pada penelitian terdahulu yaitu penelitian yang dilakukan oleh Reswanda dan Wenda Wahyu yang meneliti tentang pengaruh DPK dan FDR terhadap Penyaluran Pembiayaan pada PT.BPRS Lamtabur Jombang, menunjukkan bahwa DPK dan FDR berpengaruh signifikan terhadap penyaluran pembiayaan (Reswanda, 2015).

Penelitian Yoga Tantular Rachman menyimpulkan bahwa FDR dan CAR berpengaruh positif signifikan terhadap pembiayaan mudharabah, ROA berpengaruh positif tidak signifikan terhadap pembiayaan mudharabah. Sedangkan NPF tidak berpengaruh terhadap pembiayaan mudharabah (Yoga Tantular, 2015).

Penelitian Ferial Nurbaya yang diambil dari jurnal yang berjudul Analisis Pengaruh CAR, ROA, FDR, dan Dana Pihak Ketiga (DPK) terhadap Pembiayaan Murabahah periode Maret 2001- Desember 2009 (Studi Kasus pada PT. Bank Muamalat Indonesia, Tbk.) menunjukkan bahwa Variabel CAR, ROA, dan DPK berpengaruh positif dan signifikan terhadap pembiayaan murabahah. Sedangkan FDR tidak memiliki pengaruh terhadap pembiayaan murabahah (Ferial Nurbaya, 2013).

Pada penelitian Nur Awwalun Nisak S yang berjudul Pengaruh Bagi Hasil, CAR dan NPF terhadap Pembiayaan Musyarakah Pada Bank Muamalat Periode 2006-2014 menunjukkan bahwa variabel bagi hasil secara parsial berpengaruh secara positif dan signifikan terhadap pembiayaan musyarakah sedangkan CAR dan NPF berpengaruh secara negatif dan tidak signifikan terhadap pembiayaan musyarakah (Nur Awwalun Nisak, 2015).

Berdasarkan fenomena di atas, nampak persoalan yang menarik untuk diteliti karena terjadinya peningkatan pembiayaan secara terus menerus dan perbedaan dari hasil penelitian yang ada. Oleh karena itu, peneliti akan melakukan penelitian dengan judul "Pengaruh Rasio Keuangan Terhadap 
Pembiayaan Murabahah di Bank Pembiayaan Rakyat Syariah Adeco Langsa Tahun 2013-2016".

Tujuan dilakukannya penelitian ini adalah untuk menguji pengaruh dari DPK, FDR dan ROA terhadap pembiayaan murabahah pada BPRS Adeco Langsa. Manfaat penelitian ini adalah sebagai pengembangan ilmu pengetahuan perbankan syariah dan menjadi bahan masukan bagi BPRS Adeco Langsa.

\section{AKAD MURABAHAH}

\section{Pengertian Murabahah}

Murabahah merupakan produk pembiayaan perbankan syariah yang dilakukan dengan mengambil bentuk transaksi jual beli. Namun murabahah bukan transaksi jual beli biasa antara satu pembeli dengan satu penjual saja. Pada perjanjian murabahah, bank membiayai pembelian barang atau asset yang dibutuhkan oleh nasabahnya dengan membeli terlebih dahulu barang itu dari pemasok barang dan setelah kepemilikan barang itu secara yuridis berada di tangan bank, kemudian bank tersebut menjualnya kepada nasabah dengan menambahkan suatu mark-up/margin atau keuntungan dimana nasabah harus menyepakati berupa besar mark-up/margin yang ditambahkan ke atas harga beli bank tersebut dalam penyaluran pembiayaan berdasarkan akad murabahah (Sutan Remy, 2014 : 91).

\section{Aplikasi Murabahah Pada Perbankan Syariah}

Ciri dasar kontrak murabahah (sebagai jual beli dengan pembayaran tunda) adalah sebagai berikut : (1) si pembeli harus memiliki pengetahuan tentang biaya-biaya terkait dan tentang harga asli barang, dan batas laba (mark-up) harus ditetapkan dalam bentuk persentase dari total harga plus biaya-biayanya; (2) apa yang dijual adalah barang atau komoditas dan dibayar dengan uang; (3) apa yang diperjualbelikan harus ada dan dimiliki oleh si 
penjual dan si penjual harus mampu menyerahkan barang itu kepada si pembeli; dan (4) pembayarannya ditangguhkan (Muhammad, 2005 : 122).

\section{Dana Pihak Ketiga}

Dana pihak ketiga (DPK) merupakan dana yang dipercayakan masyarakat (di luar bank) kepada bank berdasarkan perjanjian penyimpanan dana. Dana-dana yang dihimpun dari masyarakat ternyata merupakan sumber dana terbesar yang paling diandalkan oleh bank, bisa mencapai 80\%-90\% dari seluruh dana yang dikelola oleh bank. Pos-pos ini terdiri dari simpanan dalam bentuk giro, deposito, dan tabungan (Ferial Nurbaya : 2013)

\section{NPF (Non Performing Financing)}

NPF adalah rasio yang membandingkan antara total pembiayaan bermasalah terhadap total pembiayaan yang disalurkan dalam bentuk presentase (Nuke Wulandari, 2016)

Rumus untuk mencari NPF adalah sebagai berikut:

Non Fer forming Financing (NPF) $=\frac{\text { Jlh Pembiayaan Bermasalah }}{\text { Total Pembiayaan }} \times 100 \%$

Non Performing Financing (NPF) adalah rasio kualitas aset yang menghitung perbandingan antara Total Pembiayaan Non Lancar (Koletibilitas 2, 3, 4 dan 5) dengan Total Pembiayaan Bank. Semakin tinggi nilai Non Performing Financing (NPF) menunjukkan bahwa pembiayaan bermasalah semakin meningkat. Apabila pembiayaan bermasalah semakin meningkat hingga mencapai batas tertentu, maka bank tersebut dilarang menyalurkan pembiayaan sementara waktu dan harus menurunkan nilai Non Performing Financing (NPF) sesuai dengan ketentuan Bank Indonesia sehingga hal ini dapat mengganggu aktivitas penyaluran pembiayaan. (Reswanda, 2015)

Financing to Deposit Ratio (FDR) 
Financing to Deposit Ratio (FDR) merupakan seberapa jauh kemampuan bank dalam membayar kembali penarikan dana yang dilakukan deposan dengan mengandalkan pembiayaan yang diberikan sebagai sumber likuiditasnya. Batas maksimum untuk Financing FDR adalah sebesar 110 \%, dimana apabila melebihi batas tersebut berarti likuiditas sudah termasuk kategori buruk, sebagian praktisi perbankan menyepakati batas aman dari FDR adalah sebesar $80 \%$ dengan batas toleransi antara $85 \%$ - 100 \%.(Muhammad, $2005: 114-116)$

Adapun rumus untuk mencari FDR adalah sebagai berikut : (Yoga Tantular, 2015)

Financing To Deposit Ratio $(F D R)=\frac{\text { Pembiayaan }}{\text { Total Dana Pihak Ketiga }} \times 100 \%$ Sesuai dengan ketentuan Bank Indonesia bahwa rasio FDR minimal 75\% dan tidak boleh melebihi $110 \%$. Dengan rasio FDR diantara tingkatan tersebut menandakan bahwa bank syariah menjalankan fungsi intermediasi dengan baik. Baiknya bank mampu menjaga nilai FDR hanya diantara $80 \%$ hingga $90 \%$. Dengan FDR $100 \%$ atau 110\% menandakan bank mampu menyalurkan dana melebihi batas DPK yang dimiliki dengan begitu tingkat perolehan keuntungan atau bagi hasil yang diterima bank akan semakin banyak. Tetapi semakin tinggi rasio ini mempengaruhi likuiditas bank karena nantinya bank tidak memiliki cukup cadangan dana untuk memenuhi permintaan kebutuhan dana masyarakat. Kemampuan menjalankan fungsi intermediasi secara baik dapat digunakan rasio FDR sebagai indikatornya. Semakin tinggi rasio FDR maka bank tersebut semakin baik dalam menjalankan fungsi intermediasinya. Semakin tinggi FDR maka pembiayaan yang disalurkan juga semakin meningkat. Demikian sebaliknya jika terjadi penurunan FDR maka pembiayaan yang disalurkan juga mengalami penurunan (Yoga Tantular, 2015). 


\section{Kerangka Pemikiran Teoritis}

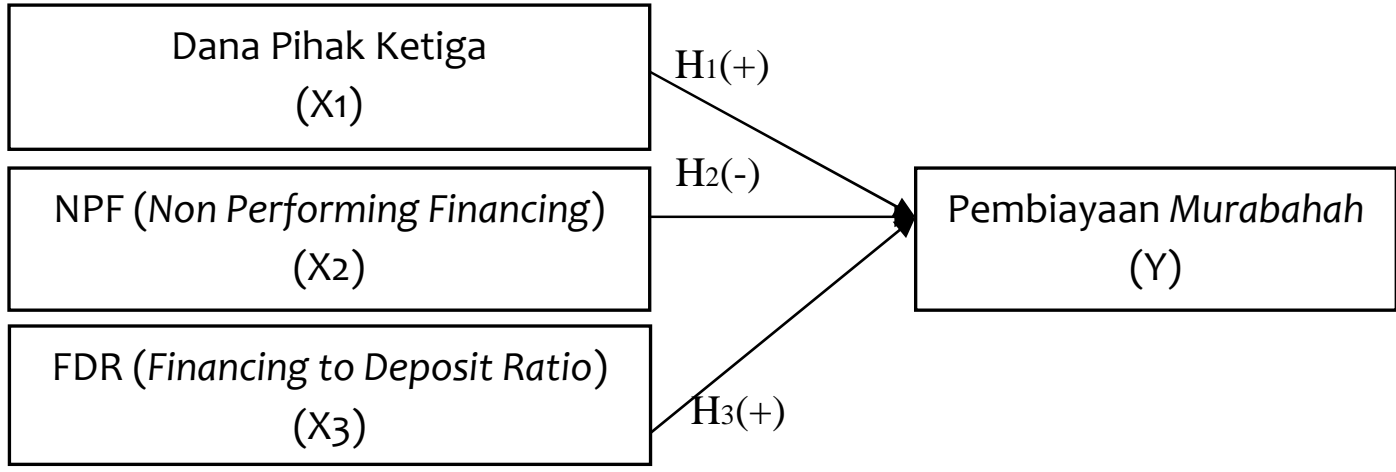

Keterangan :

$\mathrm{X}_{1}$ : Dana Pihak Ketiga (DPK)

$\mathrm{X}_{2}$ : Non Performing Financing (NPF)

$\mathrm{X}_{3}$ : Financing to Deposit Ratio (FDR)

$\mathrm{Y}$ : Pembiayaan

\section{Hipotesis}

Hipotesis berdasarkan tujuan penelitian serta kerangka pemikiran teoritis terhadap penelitian ini, maka hipotesis yang diajukan adalah sebagai berikut : H1 : Dana Pihak Ketiga (DPK) berpengaruh positif dan signifikan terhadap Pembiayaan Murabahah PT. BPRS Adeco periode Maret 2013-Desember 2016

$\mathrm{H}_{2}$ : Non Performing Financing (NPF) berpengaruh negatif dan signifikan terhadap Pembiayaan Murabahah PT. BPRS Adeco periode Maret 2013Desember 2016

H3 : Financing to Deposit Ratio (FDR) berpengaruh positif dan signifikan terhadap Pembiayaan Murabahah PT. BPRS Adeco periode Maret 2013Desember 2016

\section{METODE}

Penelitian ini dilakukan pada PT. BPRS Adeco. Sebagai perbankan pertama yang kantor pusatnya di wilayah timur di Ibukota Provinsi Aceh, PT. BPRS Adeco diharapkan memiliki dokumentasi data pembiayaan Murabahah yang cukup lengkap. Data yang digunakan dalam penelitian ini adalah data 
triwulanan mulai dari triwulan pertama tahun 2013 hingga triwulan keempat tahun 2016. Data DPK, NPF dan FDR juga diambil pada periode waktu yang sama. Seluruh data merupakan data time series triwulanan. Data jumlah pembiayaan Murabahah berasal dari neraca triwulanan yang dipublikasikan di website resmi Bank Indonesia (www.bi.go.id). Sedangkan data DPK, NPF dan FDR berasal dari perhitungan rasio keuangan triwulanan yang dipublikasikan.

Teknik analisis data dalam penelitian ini meliputi uji asumsi klasik dan analisis regresi berganda. Adapun model persamaan regresi berganda adalah sebagai berikut :

$Y=b_{0}+b_{1} X_{1}+b_{2} X_{2}+b_{3} X_{3}+e$

Untuk mengetahui seberapa besar pengaruh variable DPK, NPF dan FDR terhadap pembiayaan murabahah maka diperlukan pengujian hipotesis yakni uji F (uji simultan), koefisien determinasi dan uji t (uji parsial).

Tabel 2 : Data Kuantitatif BPR Syariah ADECO

\begin{tabular}{|l|l|l|l|l|l|}
\hline No & Keterangan & $\begin{array}{l}\text { DPK } \\
\text { (Jutaan } \\
\text { Rupiah) }\end{array}$ & $\begin{array}{l}\text { NPF } \\
(\%)\end{array}$ & $\begin{array}{l}\text { FDR } \\
(\%)\end{array}$ & $\begin{array}{l}\text { Pembiayaan } \\
\text { Murabahah } \\
\text { (Jutaan Rupiah) }\end{array}$ \\
\hline 1 & Maret 2013 & $1,950,060$ & 7.89 & 90.89 & $4,518,393$ \\
\hline 2 & Juni 2013 & $1,667,916$ & 6.80 & 106.22 & $5,018,959$ \\
\hline 3 & September 2013 & $1,908,748$ & 7.65 & 102.23 & $5,131,121$ \\
\hline 4 & Desember 2013 & $2,600,270$ & 6.77 & 97.63 & $5,602,849$ \\
\hline 5 & Maret 2014 & $2,840,447$ & 6.52 & 104.37 & $6,365,663$ \\
\hline 6 & Juni 2014 & $3,165,279$ & 6.15 & 101.70 & $7,060,365$ \\
\hline 7 & September 2014 & $3,755,340$ & 5.86 & 93.85 & $7,078,188$ \\
\hline 8 & Desember 2014 & $4,145,018$ & 4.99 & 91.15 & $7,382,729$ \\
\hline 9 & Maret 2015 & $4,731,543$ & 4.46 & 93.92 & $8,487,715$ \\
\hline 10 & Juni 2015 & $4,574,034$ & 4.83 & 100.92 & $9,016,343$ \\
\hline 11 & September 2015 & $4,521,343$ & 4.97 & 113.98 & $10,305,720$ \\
\hline 12 & Desember 2015 & $5,090,301$ & 4.42 & 81.07 & $10,673,778$ \\
\hline 13 & Maret 2016 & $5,744,913$ & 4.91 & 84.35 & $12,653,379$ \\
\hline 14 & Juni 2016 & $4,866,597$ & 4.31 & 95.47 & $14,104,130$ \\
\hline 15 & September 2016 & $5,586,769$ & 4.24 & 89.83 & $14,860,712$ \\
\hline 16 & Desember 2016 & $2,600,270$ & 3.96 & 92.31 & $15,964,520$ \\
\hline
\end{tabular}




\section{Pergerakan Variabel Penelitian}

Analisis pergerakan variabel penelitian dari periode 2013 sampai dengan 2016 adalah sebagai berikut :

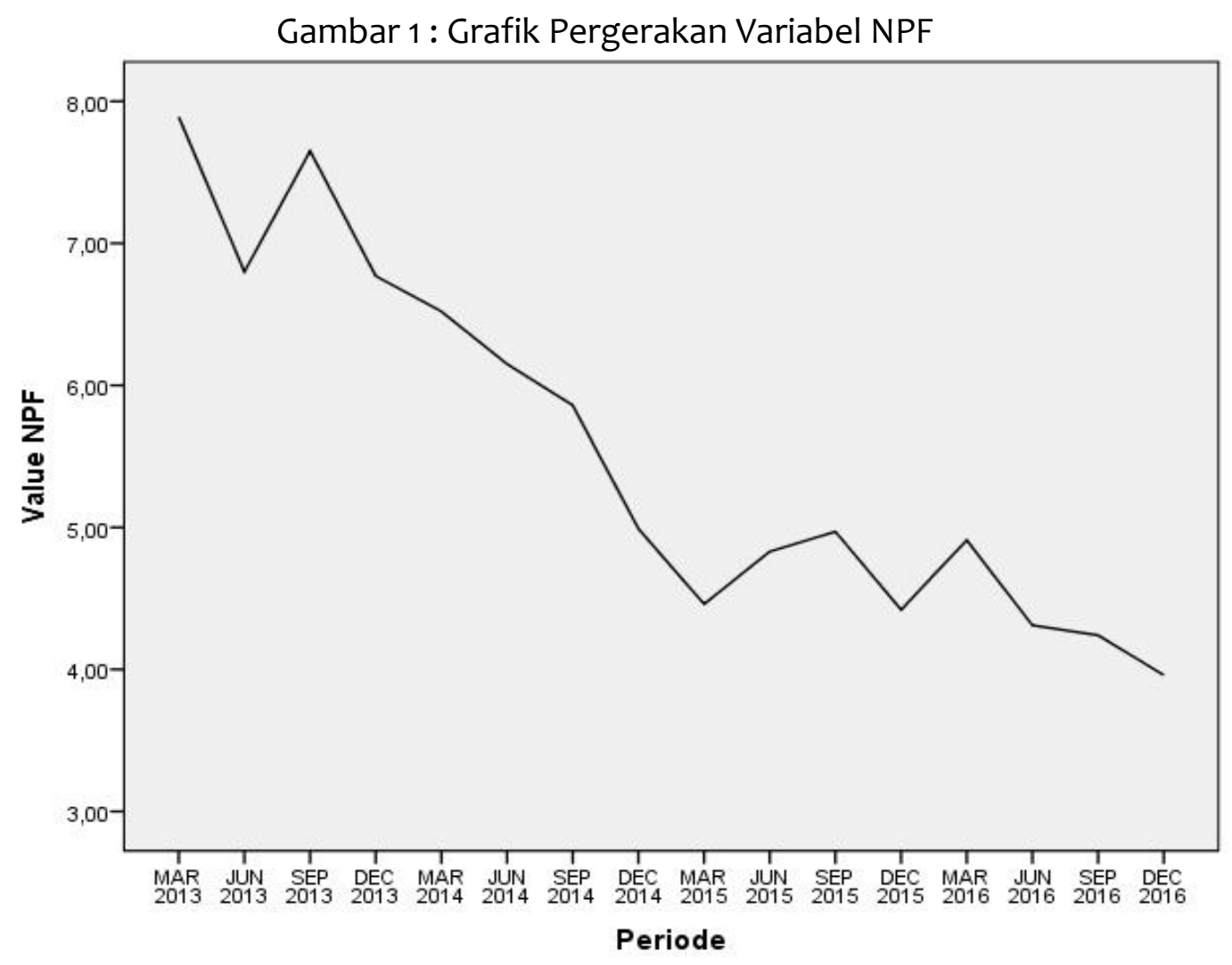

Grafik di atas merupakan perkembangan rata-rata NPF Bank Pembiayaan Rakyat Syariah Adeco Langsa selama periode 2013 sampai dengan 2016. NPF pada BPRS ini memiliki pergerakan yang naik turun selama periode 2013 sampai 2016. Rasio NPF paling tinggi adalah pada Maret 2013 yaitu sebesar 7.89 persen, kemudian di kuartal berikutnya angka NPF turun menjadi 6.80 persen. Adapun tingkat NPF paling rendah adalah pada bulan Desember 2016 yaitu sebesar 3.96 persen yang menandakan semakin sedikit nasabah pembiayaan yang bermasalah atau tidak melunasi kewajiban lancarnya.

Gambar 2 : Grafik Pergerakan Variabel FDR 


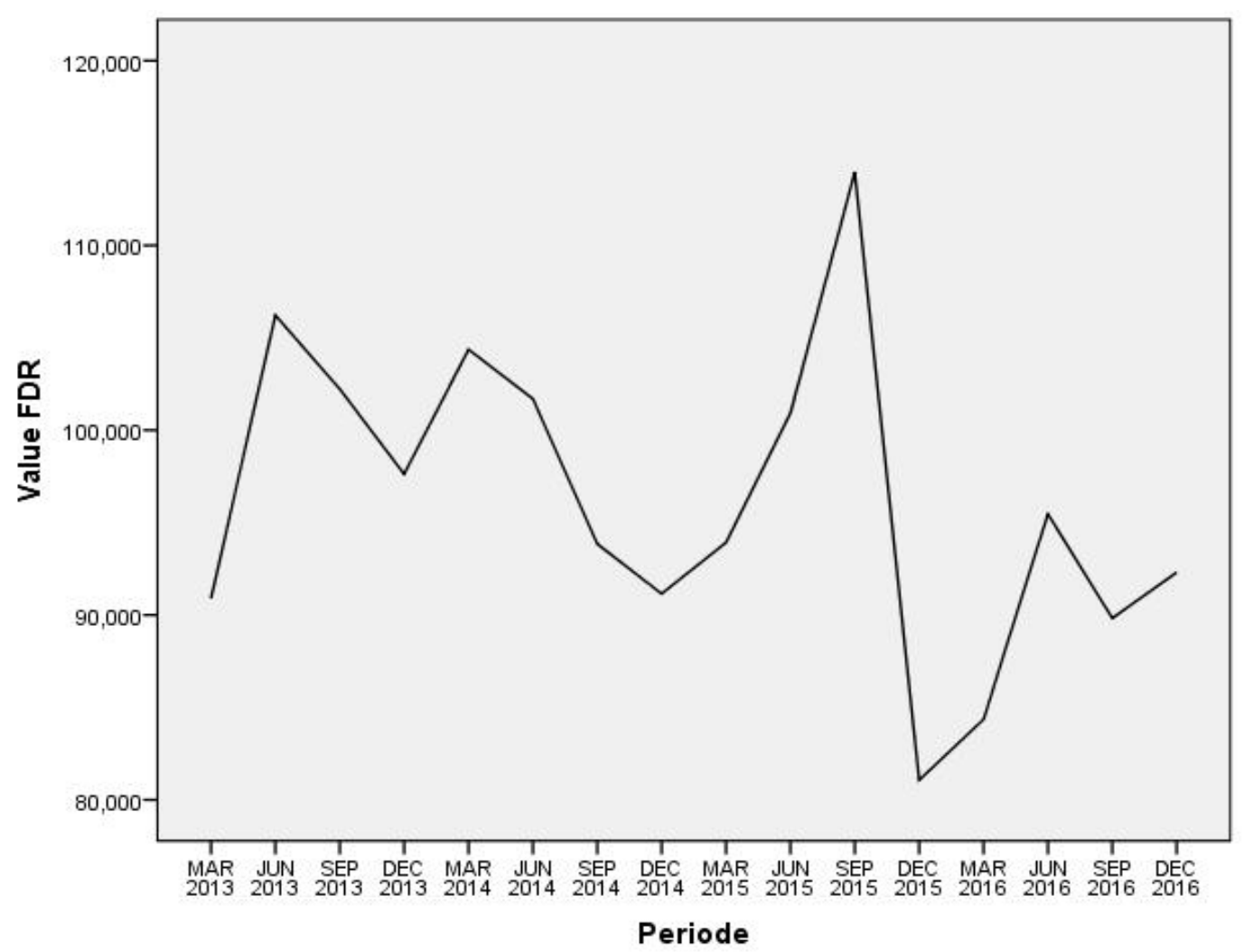

Grafik di atas merupakan perkembangan rata-rata FDR Bank Pembiayaan Rakyat Syariah Adeco Langsa selama periode 2013 sampai dengan 2016. FDR pada BPRS ini memiliki pergerakan yang naik turun. Nilai FDR paling tinggi adalah pada bulan September 2015 yaitu sebesar 113.98. Sedangkan nilai FDR paling rendah adalah pada bulan Desember 2015 yakni sebesar 81.07.

Gambar 3 : Grafik Pergerakan Variabel Pembiayaan Murabahah

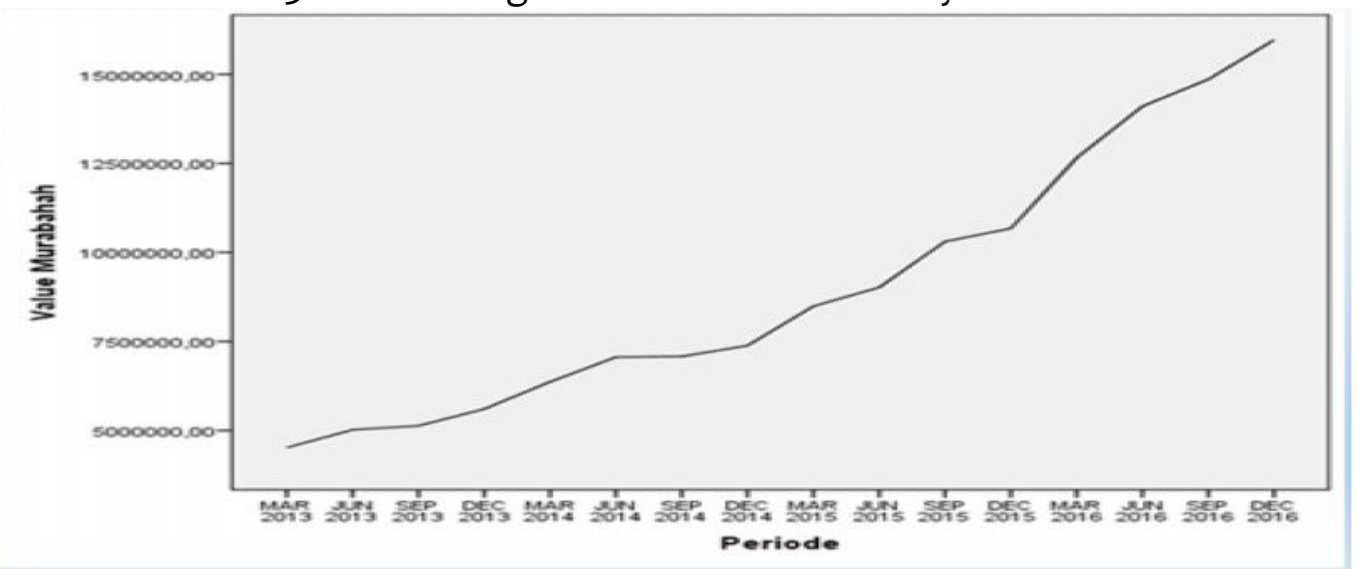


Grafik di atas merupakan perkembangan rata-rata Pembiayaan Murabahah Bank Pembiayaan Rakyat Syariah Adeco Langsa selama periode 2013 sampai dengan 2016. Pembiayaan Murabahah pada BPRS ini memiliki pergerakan yang terus meningkat setiap tahunnya. Total pembiayaan Murabahah yang paling banyak disalurkan adalah pada bulan Desember 2016.

\section{ANALISIS DATA}

\section{Uji Asumsi Klasik}

Uji normalitas ini bertujuan untuk menguji apakah dalam sebuah model regresi, variabel independen dan dependen memiliki distribusi yang normal. Model regresi yang baik adalah model dengan distribusi yang normal atau mendekati normal. Grafik normal P-P Plot digunakan untuk mendeteksi normalitas yang membandingkan distribusi kumulatif dari data sesungguhnya dengan distribusi kumulatif dari distribusi normal (Singgih Santoso : 2000, 214) Berikut hasil uji normalitas :

Gambar 4 : Hasil Uji Normalitas

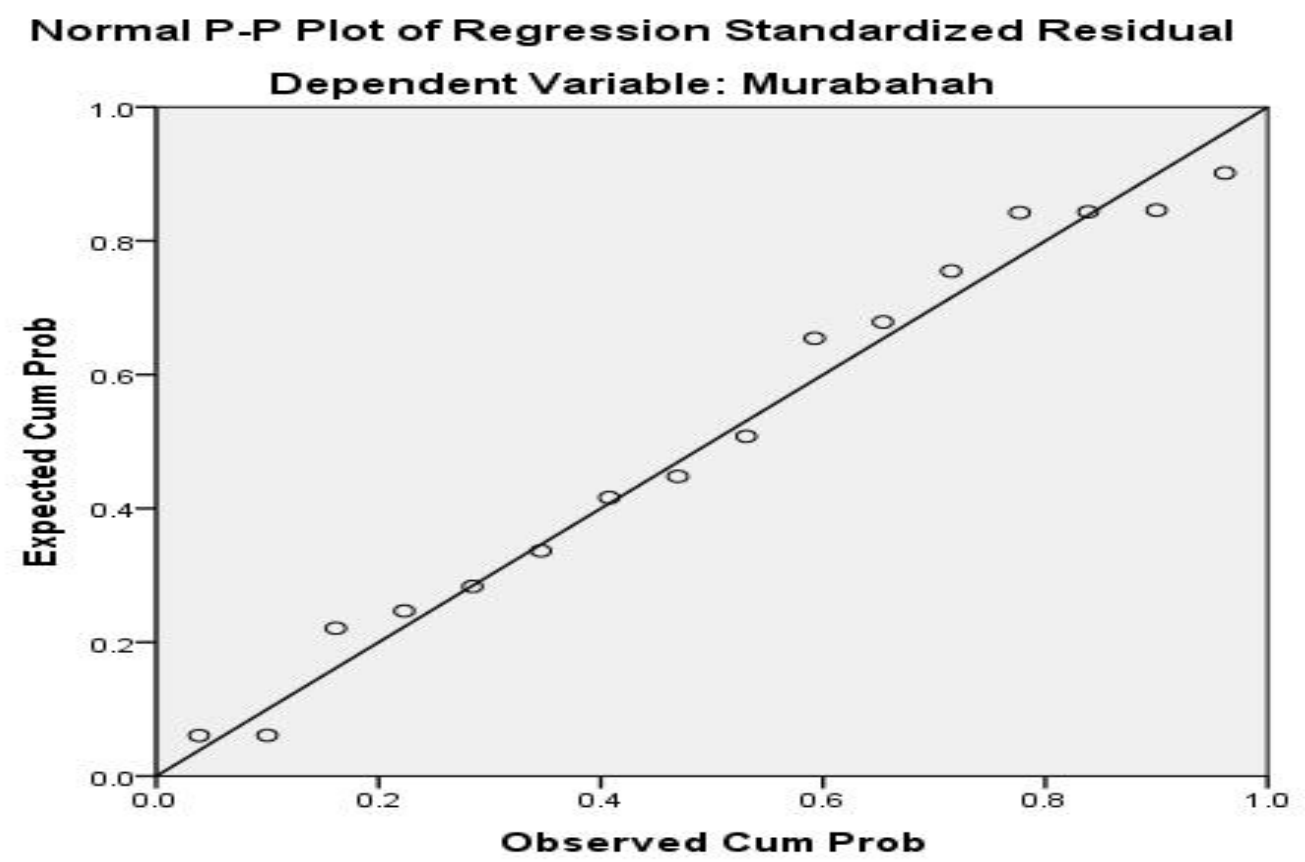


“Dari gambar diatas dapat ditarik kesimpulan bahwa data terdistribusi normal karena data menyebar di sekitar garis diagonal dan mengikuti arah garis diagonal. Hal ini menunjukkan bahwa model regresi memenuhi asumsi normalitas (Singgih Santoso : 2000, 214)

\section{Uji Multikolinieritas}

Pada dasarnya multikoliniearitas adalah suatu hubungan linear yang sempurna (mendekati sempurna) antara beberapa atau semua variabel bebas. Uji multikolinearitas digunakan untuk mengetahui ada tidaknya hubungan yang berarti antara masing-masing variabel bebas dalam model regresi (Bambang Prasetyo : 2008, 135) Berikut hasil uji multikolinieritas :

Tabel 3 : Hasil Uji Multikolinieritas

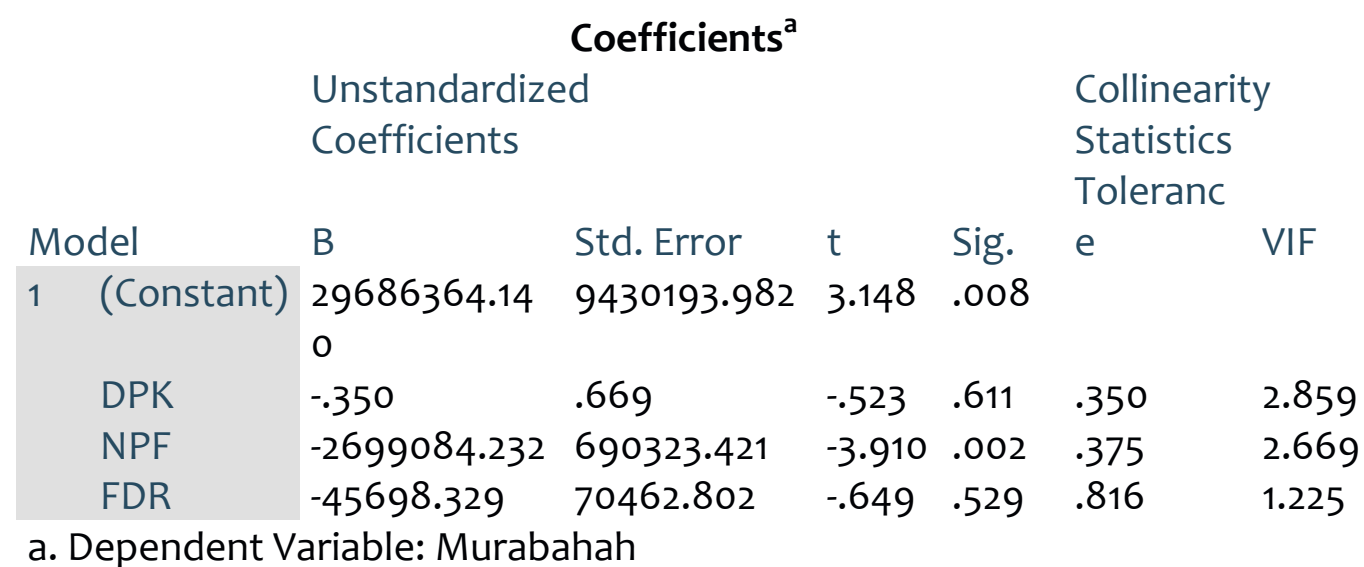

Menurut Santoso (2011) dalam buku Dwi Priyatno menyatakan pada umumnya jika VIF > 5, maka variabel tersebut mempunyai persoalan multikolinieritas dengan variabel bebas lainnya (Dwi Priyanto : 2009, 39)

Dari hasil diatas dapat diketahui bahwa variabel DPK memiliki nilai VIF sebesar 2.859, NPF (2.669) dan FDR (1.225) yang berarti bahwa semua variabel bebas yang diamati memiliki nilai lebih kecil dari 5, sehingga tidak terjadi multikolinearitas dalam variabel independen penelitian ini. 


\section{Uji Heteroskedastisitas}

Uji Heteroskedastisitas bertujuan menguji apakah dalam model regresi terjadi ketidaksamaan varians dari residual satu observasi ke observasi lain. Artinya, setiap observasi mempunyai reliabilitas yang berbeda akibat perubahan dalam kondisi yang melatarbelakangi tidak terangkum dalam spesifikasi model. Gejala heteroskedastisitas lebih sering dijumpai dalam data silang tempat daripada runtut waktu, maupun juga sering muncul dalam analisis yang menggunakan data rata-rata. (Bambang Prasetyo : 2008, 96)Berikut hasil uji heteroskedastisitas :

Gambar 5 : Hasil Uji Heteroskedastisitas

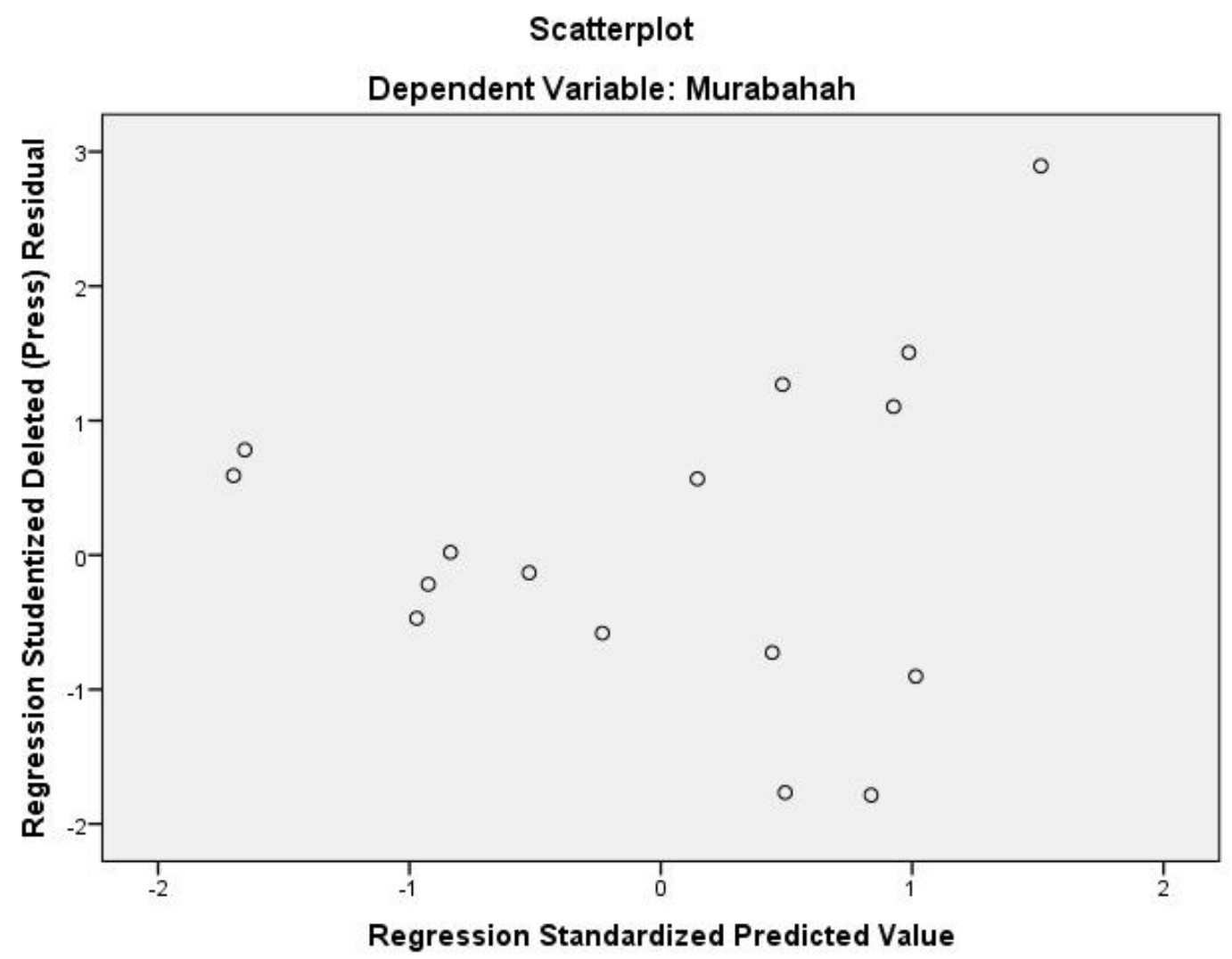

Heterokedastisitas terjadi apabila titik-titik (point-point) yang ada membentuk suatu pola tertentu yang teratur. Sedangkan dari gambar diatas dapat dilihat bahwa tidak ada pola yang jelas, serta titik-tik (point-point) 
menyebar di bawah dan di atas angka o pada sumbu $\mathrm{Y}$, maka dapat disimpulkan tidak terjadi heterokedastisitas. (Singgih Santoso : 2000, 218).

\section{Uji Autokorelasi}

Uji autokorelasi bertujuan menguji apakah dalam suatu model regresi linier ada korelasi antara pengganggu periode $t$ dengan kesalahan pada periode $\mathrm{t}-1$ (sebelum).Jika ada korelasi, maka dinamakan ada problem autokorelasi. Autokorelasi muncul karena observasi berurutan sepanjang waktu berkaitan satu sama lain. Masalah ini timbul karena residual (kesalahan pengganggu) tidak bebas dari suatu observasi ke observasi lainnya. (Mudrajad Kuncoro : 2007,90 )

Salah satu cara mengidentifikasinya adalah dengan melihat nilai DurbinWatson (D-W):

a. Jika nilai D-W di bawah -2 berarti ada autokorelasi positif

b. Jika nilai D-W diantara -2 sampai +2 berarti tidak ada autokorelasi

C. Jika nilai D-W di atas +2 berarti ada autokorelasi negative (Bambang Prasetyo : 2008, 173)

Berikut hasil uji autokorelasi :

Tabel 4 : Hasil Uji Autokorelasi

\begin{tabular}{|c|c|c|c|c|c|c|}
\hline \multicolumn{7}{|c|}{ Model Summary ${ }^{b}$} \\
\hline Model & $\mathrm{R}$ & R Square & $\begin{array}{l}\text { Adjustec } \\
\text { Square }\end{array}$ & & $\begin{array}{l}\text { Std. Error of } \\
\text { the Estimate }\end{array}$ & $\begin{array}{l}\text { Durbin- } \\
\text { Watson }\end{array}$ \\
\hline 1 & $.866^{\mathrm{a}}$ & .749 & .687 & & 2076719.504 & .886 \\
\hline
\end{tabular}

a. Predictors: (Constant), FDR, NPF, DPK

b. Dependent Variable: Murabahah

Pada tabel diatas dapat dilihat bahwa nilai Durbin Watson sebesar 0. 886 yang berarti nilai Durbin Watson berada diantara -2 sampai +2, maka dapat disimpulkan bahwa tidak ada autokorelasi pada penelitian ini. 


\section{Uji Regresi Linier Berganda}

Uji Simultan (Uji F)

Tabel 5 :Hasil Perhitungan Uji F

\begin{tabular}{|c|c|c|c|c|c|c|}
\hline \multicolumn{7}{|c|}{ ANOVA $^{\mathrm{a}}$} \\
\hline \multicolumn{2}{|c|}{ Model } & $\begin{array}{l}\text { Sum of } \\
\text { Squares }\end{array}$ & $\mathrm{df}$ & $\begin{array}{l}\text { Mean } \\
\text { Square }\end{array}$ & $\mathrm{F}$ & Sig. \\
\hline \multirow[t]{3}{*}{1} & Regression & $\begin{array}{l}15471781770 \\
0000.000\end{array}$ & 3 & $\begin{array}{l}51572605890 \\
000.000\end{array}$ & 11.958 & $.001^{b}$ \\
\hline & Residual & $\begin{array}{l}51753166780 \\
000.000\end{array}$ & 12 & $\begin{array}{l}4312763898 \\
000.000\end{array}$ & & \\
\hline & Total & $\begin{array}{l}2064709845 \\
00000.000\end{array}$ & 15 & & & \\
\hline
\end{tabular}

a. Dependent Variable: Murabahah

b. Predictors: (Constant), FDR, NPF, DPK

Hasil pada tabel di atas telah diperoleh Fhitung sebesar 11.958 dengan taraf signifikan $(\alpha)=5 \%$ (0.05) serta diketahui df1 = k-1 = 4-1 = 3 dan df2 sebesar $\mathrm{N}-\mathrm{k}=16-4=12$ adalah 3.49. Sehingga nilai Fhitung $>$ Ftabel $(11.958>3.49)$ maka Ho ditolak yang artinya ada pengaruh signifikan antara DPK, NPF dan FDR terhadap pembiayaan murabahah. Jadi pada kasus ini dapat disimpulkan bahwa DPK, NPF dan FDR secara simultan berpengaruh signifikan terhadap pembiayaan Murabahah pada BPRS Adeco Langsa.

\section{Koefisien Determinasi}

Koefisien Determinasi $\left(R^{2}\right)$ pada intinya mengukur seberapa jauh kemampuan model dalam menerangkan variasi variabel terikat. Nilai koefisien determinasi adalah antara nol dan satu. (Bambang Prasetyo : 2008, 84) Berikut adalah hasil pengamatan $R^{2}$ Square : 
Tabel 6 : Koefisien Determinasi

\begin{tabular}{|c|c|c|c|c|c|}
\hline \multicolumn{6}{|c|}{ Model Summary ${ }^{b}$} \\
\hline Model & $\mathrm{R}$ & R Square & $\begin{array}{l}\text { Adjusted } \\
\text { Square }\end{array}$ & $\begin{array}{l}\text { Std. Error of } \\
\text { the Estimate }\end{array}$ & $\begin{array}{l}\text { Durbin- } \\
\text { Watson }\end{array}$ \\
\hline 1 & $.866^{\mathrm{a}}$ & .749 & .687 & 2076719.504 & .886 \\
\hline
\end{tabular}

a. Predictors: (Constant), FDR, NPF, DPK

b. Dependent Variable: Murabahah

Tabel diatas menunjukkan besarnya adjusted $\mathrm{R}^{2}$ adalah 0.749 , hal ini berarti pembiayaan Murabahah dapat dijelaskan oleh variabel NPF dan variabel FDR sebesar $74.9 \%$ sedangkan sisanya $(100 \%-74.9 \%=25.1 \%)$ dijelaskan oleh variabel lain.

Uji t

Uji $\mathrm{t}$ bertujuan utuk menguji pengaruh masing-masing variabel independen (NPF dan FDR) terhadap variabel dependen pembiayaan Murabahah. Hasil uji analisis regresi coefficient dengan menggunakan SPSS sebagai berikut :

Tabel 7 : Hasil Perhitungan Uji t

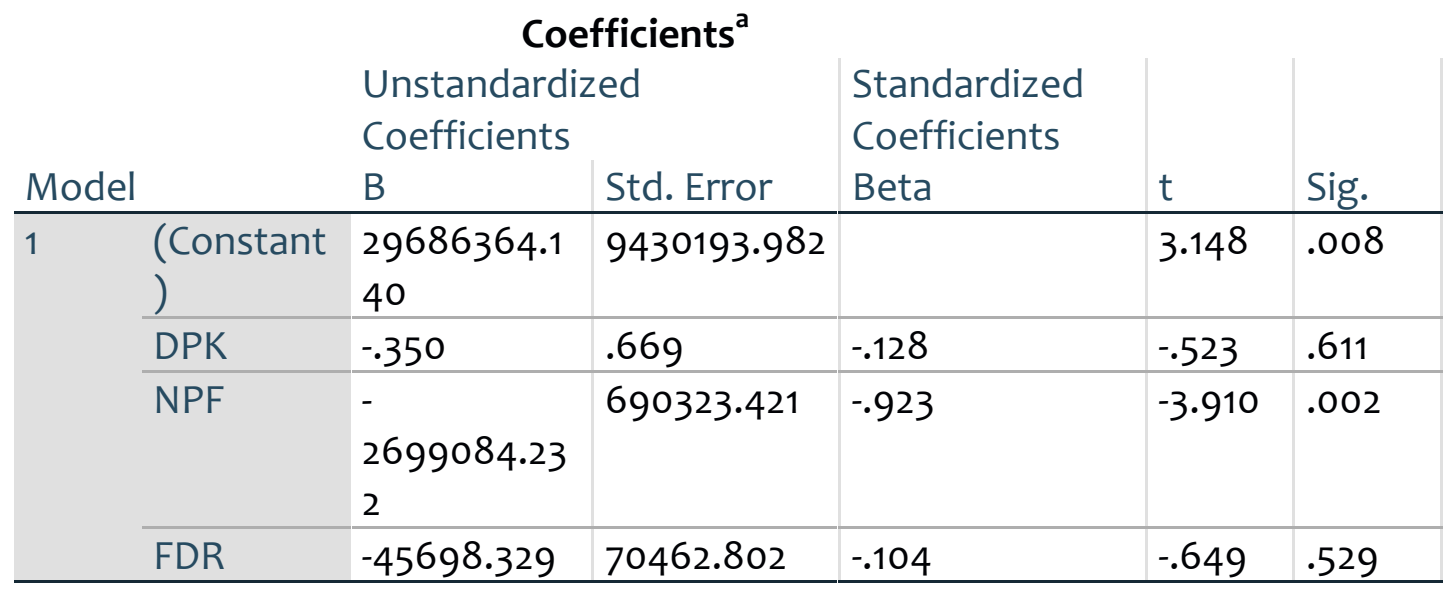

a. Dependent Variable: Murabahah

Dari tabel di atas, disusun persamaan regresi berganda sebagai berikut :

$\mathrm{Y}=256986364,140-0,350 \mathrm{X}_{1}-2699084,232 \mathrm{X}_{2}-45698,329 \mathrm{X}_{3}+e$ 
Berdasarkan persamaan regresi berganda diatas diperoleh koefisien regresi DPK sebesar -0,350 yang berarti adanya hubungan negative antara variable DPK terhadap pembiayaan murabahah. Koefisien regresi NPF sebesar - 2699084,232 mengartikan bahwa adanya hubungan negatif antara variable NPF terhadap pembiayaan murabahah. Koefisien regresi FDR sebesar 45698,329 mengartikan bahwa adanya hubungan negatif antara variable FDR terhadap pembiayaan murabahah.

Dari hasil Uji-t dilakukan pembahasan hipotesis berikut ini :

1. H1 : Dana Pihak Ketiga (DPK) berpengaruh negatif dan tidak signifikan terhadap pembiayaan Murabahah pada PT. BPRS AdecoLangsa.

Hasil analisis regresi berganda menunjukkan DPK memiliki t hitung $<\mathrm{t}$ tabel $(-0.523<0.69745)$ yang berarti $\mathrm{H} 1$ ditolak. Hal ini juga didukung oleh nilai signifikansi DPK (0.611) $>0.05$

2. $\mathrm{H}_{2}$ : Non Performing Financing (NPF) berpengaruh negatif dan signifikan terhadap pembiayaan Murabahah pada PT. BPRS AdecoLangsa.

Hasil analisis regresi berganda menunjukkan NPF memiliki t hitung $<t$ tabel $(-3.910<0.69745)$ yang berarti $\mathrm{H} 2$ diterima. Hal ini juga didukung oleh nilai signifikansi NPF $(0.002)<0.05$

3. H3 : Financing to Deposit Ratio (FDR) berpengaruh negatif dan tidak signifikan terhadap pembiayaan Murabahah pada PT. BPRS AdecoLangsa. Hasil analisis regresi berganda menunjukkan FDR memiliki $t$ hitung $<\mathrm{t}$ tabel $(-0.649<0.69745)$ yang berarti $\mathrm{H}_{3}$ ditolak. Hal ini juga didukung oleh nilai signifikansi NPF (0.529) >0.05

Dari pembahasan hipotesis. diatas dapat disimpulkan bahwa DPK dan FDR secara parsial tidak berpengaruh signifikan terhadap pembiayaan murabahah. Hasil ini bertolak belakang dengan penelitian Wenda Wahyu (2015) yang menyebutkan bahwa variabel DPK dan FDR berpengaruh signifikan terhadap penyaluran pembiayaan pada PT.BPRS Lantabur Jombang, 
menunjukkan bahwa DPK dan FDR berpengaruh signifikan terhadap penyaluran pembiayaan.

Sedangkan NPF secara parsial berpengaruh signifikan terhadap pembiayaan murabahah. Hasil ini sesuai dengan penelitian sebelumnya yang dilakukan oleh Nur Awwalun Nisak S (2015) yang berjudul Pengaruh Bagi Hasil, CAR dan NPF terhadap Pembiayaan Musyarakah Pada Bank Muamalat Periode 2006-2014 menunjukkan bahwa variabel CAR dan NPF secara berpengaruh secara negatif dan tidak signifikan terhadap pembiayaan musyarakah, hanya saja pada penelitian ini nilainya signifikan.

\section{PEMBAHASAN}

Model persamaan regresi berganda :

$$
\mathrm{Y}=256986364,140-0,350 \mathrm{X}_{1}-2699084,232 \mathrm{X}_{2}-45698,329 \mathrm{X}_{3}+e
$$

\section{Analisis Pengaruh DPK terhadap Pembiayaan Murabahah}

Nilai koefisien regresi sebesar -0.350 dengan nilai signifikan sebesar 0.611 yang berarti lebih besar dari 0.05. Artinya jika setiap penambahan variabel DPK sebesar satu persen sedangkan variabel lain dianggap konstant, maka pembiayaan Murabahah menurun akan tetapi nilainya tidak signifikan.

\section{Analisis Pengaruh NPF terhadap Pembiayaan Murabahah}

Berdasarkan hasil data olahan SPSS pada penelitian ini menyatakan bahwa NPF berpengaruh secara negatif dan signifikan. Nilai koefisien regresi sebesar -699084,232 dengan nilai signifikan sebesar 0.002 yang berarti lebih kecil dari 0.05. Artinya jika setiap penambahan variabel NPF sebesar satu persen sedangkan variabel lain dianggap konstant, maka pembiayaan Murabahah menurun dan nilainya signifikan.

\section{Analisis Pengaruh FDR terhadap Pembiayaan Murabahah}

Berdasarkan hasil data olahan SPSS pada penelitian ini menyatakan bahwa FDR terdapat pengaruh secara negatif dan tidak signifikan. Nilai koefisien regresi sebesar $-45698,329$ dengan nilai signifikan sebesar 0.529 
yang berarti lebih besar dari 0.05. Artinya jika setiap penambahan FDR sebesar satu persen sedangkan variabel lain dianggap konstant, maka pembiayaan Murabahah menurun akan tetapi nilainya tidak signifikan.

\section{Simpulan}

Berdasarkan hasil penelitian dan pembahasan diatas maka dapat ditarik beberapa kesimpulan sebagai berikut :

a. Hasil uji t untuk variabel $X_{1}$ (DPK) diperoleh t hitung sebesar -0.523 dengan signifikansi 0.611. Nilai signifikansi lebih besar dari 0,05 (0.611 > 0.05) maka diperoleh $\mathrm{t}$ tabel dengan $\mathrm{df}=11$ adalah sebesar 0.69745. Maka diperoleh $\mathrm{t}$ hitung $(-0.527)<t$ tabel (0.69548) sehingga H1 ditolak. Maka DPK tidak berpengaruh signifikan terhadap penyaluran pembiayaan Murabahah.

b. Hasil uji t untuk variabel $X_{2}$ (NPF) diperoleh t hitung sebesar -3.910 dengan signifikansi 0.002. Nilai signifikansi lebih besar 0,05 $(0.002<0.05)$ maka diperoleh $\mathrm{t}$ tabel dengan $\mathrm{df}=11$ adalah sebesar 0.69745. Maka diperoleh $\mathrm{t}$ hitung $(-3.910)<\mathrm{t}$ tabel $(0.69745)$ sehingga $\mathrm{H} 2$ diterima. Maka NPF berpengaruh secara negatif dan signifikan terhadap penyaluran pembiayaan Murabahah.

c. Hasil uji parsial untuk variabel $X_{3}$ (FDR) menunjukan bahwa $t$ hitung sebesar -0.649 dengan signifikansi 0,529. Nilai signifikansi lebih besar 0,05 (0.529 > 0.05) sehingga $\mathrm{H} 3$ ditolak. Maka FDR tidak berpengaruh signifikan terhadap penyaluran pembiayaan Murabahah.

d. Hasil pengujian secara simultan variabel independen yang terdiri dari rasio keuangan (DPK, NPF, FDR) dan variabel dependen adalah pembiayaan murabahah, menunjukan bahwa variabel independen secara bersamasama ada pengaruh yang signifikan terhadap penyaluran pembiayaan murabahah. Hal ini ditunjukan bahwa F hitung sebesar 11.958 lebih besar dari F tabel 3,49. 


\section{PUSTAKA ACUAN}

Al Arif, M Nur Rianto. 2012. Lembaga Keuangan Syariah, Bandung : CV Pustaka Setia,

Ghazali, Imam. 2011. Analisis Multivariate dengan Program IBM SPSS 19, Semarang : PT Badan Penerbit Universitas Diponegoro.

Muhammad. 2005. Manajemen Pembiayaan Bank Syariah, Yogyakarta : UPP AMP YKPN,

Nisak, Nur Awwalun. 2015. "Pengaruh Bagi Hasil, CAR dan NPF terhadap Pembiayaan Musyarakah Pada Bank Muamalat Periode 2006-2014" (Fakultas Ekonomi dan Bisnis Islam, UIN Sunan Ampel, Surabaya)

Nurbaya, Ferial. 2013. Analisis Pengaruh CAR, ROA, FDR, dan Dana Pihak Ketiga (DPK) terhadap Pembiayaan Murabahah Periode Maret 2001-Desember 2009 (Studi Kasus pada PT. Bank Muamalat Indonesia, Tbk). Skripsi Fakultas Ekonomi Universitas Diponegoro Semarang.

Priyanto, Dwi. 2009. Mandiri Belajar SPSS, Jakarta : PT Buku Kita.

Reswanda, Wenda Wahyu. 2015. "Pengaruh Dana Pihak Ketiga, Capital Adequecy Ratio, Financing to Deposit Ratio, dan Non Performing Financing Terhadap Penyaluran Pembiayaan Pada PT BPRS Lantabur Jombang", Jurnal Fakultas Ekonomi Universitas Widyatama Narotama Surabaya.

Rachman, Yoga Tantular. 2015. "Pengaruh Financing to Deposit Ratio (FDR), Non Performing Financing (NPF), Return On Assets (ROA), dan Capital Adequacy Ratio (CAR) terhadap Pembiayaan Mudharabah (Survey pada Bank Syariah yang Listing di Bursa Efek Indonesia pada Tahun 20092013)", Jurnal Universitas Widyatama Mataram.

Sahara, Ratna dan Nunung Nurul Hidayah. 2008. Analisis Perbandingan Kinerja Keuangan Bank Muamalat Indonesia Periode 1992-1998 dan 1999-2006. Jurnal Universitas Al Azhar Indonesia.

Sjahdeini, Sutan Remy. 2014.Perbankan Syariah (Produk-Produk dan AspekAspek Hukumnya), Jakarta : PT Adhitya Andrebina Agung.

Wulandari, Nuke. 2016. Pengaruh Capital Adequacy Ratio, Non Performing Financing, Dan Financing to Deposit Ratio Terhadap Return On Assets 
dan Return on Equity Pada Bank Pembiayaan Rakyat Syariah (Studi pada BPRS di Wilayah Jabodetabek). Skripsi Fakultas Syariah dan Hukum, UIN Syarif Hidayatullah Jakarta. 
